\title{
COMPARISON BEHAVIOR OF FLEXURAL CAPACITY CASTELLATED BEAM OF HEXAGONAL OPENING WITH CIRCLE OPENING
}

\author{
Ida Barkiah ${ }^{1 *}$, Arya Rizki Darmawan ${ }^{1}$ \\ ${ }^{1}$ Assistant Professor, Department of Civil Engineering, \\ University of Lambung Mangkurat (ULM), Banjarmasin South Borneo, Indonesia \\ *Corresponding Author
}

\begin{abstract}
To increase the flexural capacity of the WF profile, it can be done by modifying the geometry into a castellated beam. Castellated beam has several variations of opening shapes. The author in 2020 has obtained the results of the flexural behavior of hexagonal opening castellated beams, obtained the optimum flexural capacity at $45^{\circ}$ hexagonal opening angle variations. In this study, the author want to obtain differences in flexural strength produced by hexagonal castellated beam openings with circle openings. ANSYS numerical testing was carried out to obtain the behavior of the castellated beam. The test model made is a castellated beam with circle openings with several variations of S/Do and D/Do parameters. From the results of numerical testing, it is found that the optimum castellated circle opening is $S / D o=1.3 ; D / D o=1.4$. With the value of $P_{y i e l d}=57 \mathrm{kN}$ and $P_{\text {ultimate }}=84 \mathrm{kN}$. From the results of the castellated beam's flexural capacity, the circle opening is compared with the hexagonal bending capacity. Hexagonal openings get better results than circle openings. Castellated hexagonal apertures get $P_{\text {yield }}=61.7 \mathrm{kN}$ and $P_{\text {ultimate }}=95 \mathrm{kN}$. The deformation experienced by castellated circle openings has a value greater than that of hexagonal openings. This shows that the hexagonal opening has a more excellent inertial stiffness value than the circle opening. Because the circle opening has a larger opening area than the hexagonal opening, it causes a smaller inertial stiffness value.
\end{abstract}

Keywords: flexural, circle opening, hexagonal opening, structural steel, bending

Cite this Article: Ida Barkiah and Arya Rizki Darmawan, Comparison Behavior of Flexural Capacity Castellated Beam of Hexagonal Opening with Circle Opening, International Journal of Civil Engineering and Technology (IJCIET), 12(8), 2021, pp. 32-43.

https://iaeme.com/Home/issue/IJCIET?Volume $=12 \&$ Issue $=8$ 


\section{INTRODUCTION}

Beam elements in steel structures often use WF cross-section profiles. The WF profile has a limited capacity to bear the load at a certain length of the span. If the load element is large, then a large WF profile is also needed. This causes the weight and cost of the resulting structure to increase. So it is necessary to increase the load capacity of the WF beam.

To increase the flexural capacity of the structural elements, modifications to the structure's geometry are carried out. In conventional WF steel beams, geometry modification is made by making castellated steel beams. Castellated beam starts from a cross-sectional profile of WF, which is cut into two pieces with several variations of cut patterns, then put back together into a single unified beam to carry the load [1]-[4]. Samadhan et al [5], by reuniting the two pieces that were cut, the height of the beam will increase from the original, so this will make the value of the inertia stiffness of the beam will increase. This castellated beam aims to increase the flexural capacity of the beam. In addition to increasing the flexural capacity, castellated beams can also produce a lightweight structure. The resulting structure will be lighter than conventional WF beams [6]. There are several variations in the shape of the castellated beam opening, namely hexagonal, sinusoidal, diamond, and circle openings [6]-[9].

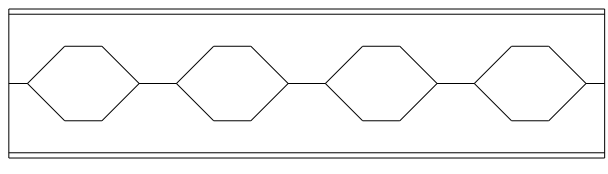

Figure 1 Castellated beam hexagonal opening

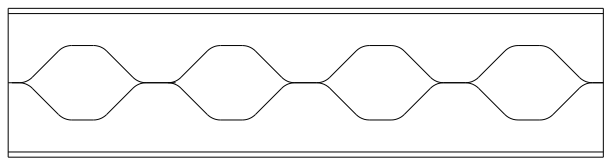

Figure 2 Castellated beam sinusoidal opening

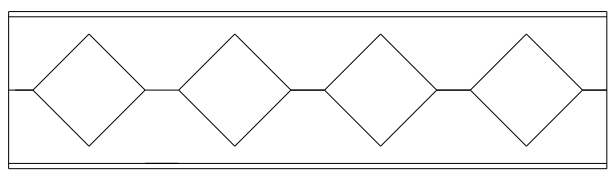

Figure 3 Castellated beam diamond opening

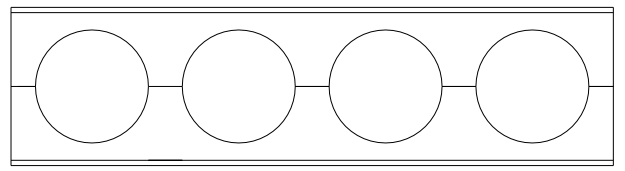

Figure 4 Castellated beam circle opening

In 2020 the author [10] had conducted a comparative study of flexural capacity between conventional WF beams and hexagonal opening castellated beams. In this study, empirical and numerical analytical tests of ANSYS were carried out. The variations in the hexagonal opening angles are $0^{0}$ (conventional WF beam), $20^{\circ}, 30^{\circ}, 45^{\circ}, 50^{\circ}$, and $60^{\circ}$. This study found that the flexural capacity was increased by applying castellated beam geometry with hexagonal openings. The greater the angle of the given opening, the greater the value of the increase in flexural capacity, but the optimum angle of hexagonal opening occurs at $45^{\circ}-50^{\circ}$.

Based on the results of previous studies, the authors wanted to compare the flexural capacity between the hexagonal and circle opening castellated beams. This research aims to obtain the 
shape of the castellated opening that can provide the most optimum flexural capacity between hexagonal openings and circle openings.

\section{THE MATERIALS AND METHOD}

\subsection{Material Properties}

The method used in this research is numerical testing with the help of ANSYS software. The material used to perform ANSYS modeling in this study is steel sheet material from Malang City, which Arya previously researched in 2017 with research on Corrugated Plate Girder Behavior [11].

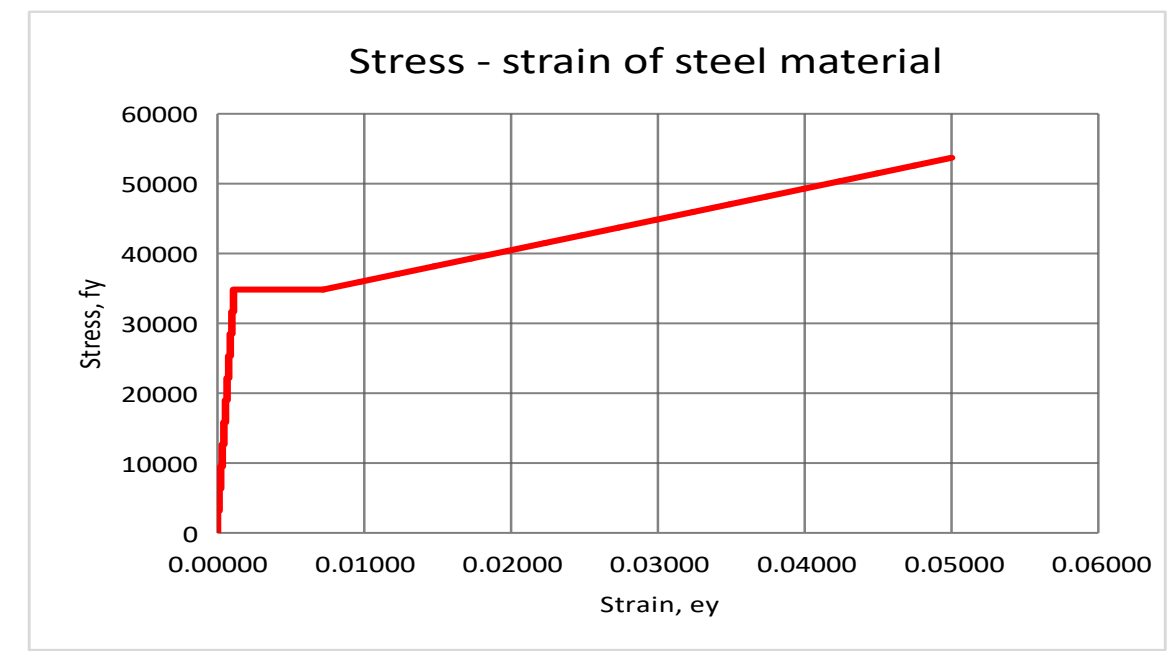

Figure 5 The stress-strain curve of the steel material used in the study

Table 1 Material Properties

\begin{tabular}{ccc}
\hline Properties & Value & Units \\
\hline Yield stregth, $\mathrm{f}_{\mathrm{y}}$ & 240 & $\mathrm{Mpa}$ \\
Ultimite Strength, $\mathrm{f}_{\mathrm{u}}$ & 370 & $\mathrm{Mpa}$ \\
Modulus Elastis, $\mathrm{E}_{\mathrm{s}}$ & 200000 & $\mathrm{Mpa}$ \\
Yield strain, $\mathrm{e}_{\mathrm{y}}$ & 0.0012 & \\
Plateau strain, $\mathrm{e}_{\mathrm{sh}}=6 * \mathrm{e}_{\mathrm{y}}$ & 0.0072 & \\
Ultimite strain, $\mathrm{e}_{\mathrm{su}}$ & 0.05 & \\
\hline
\end{tabular}

The material will be inputted into the ANSYS software using Non-Linear Structural Steel data material with an isotropic multilinear system. The selection of the non-linear data material is so that the results of running numerical ANSYS can reach the fracture phase to reflect the actual behavior of the structure. Then with a multilinear system, it is possible to input the points of the stress-strain relationship as shown in Figure 5 in ANSYS.

\subsection{Model Speciments}

The model that will be tested in this study is a hexagonal and circle opening castellated beam. The hexagonal opening model refers to the results of the author's research in 2020 [10], a WF $150 \times 75 \times 5 \times 7$ steel profile with a length of $2000 \mathrm{~mm}$ used as a hexagonal castellated beam with an optimum angle of $45^{\circ}$. Illustrations of making castellated beams with hexagonal openings can be seen in Figure 6. 


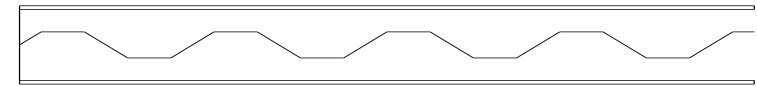

(a)

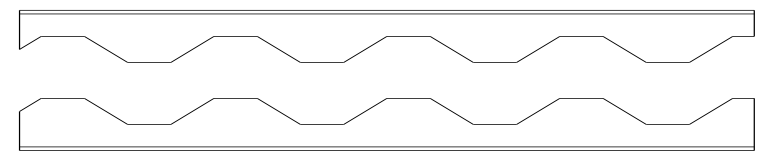

(b)

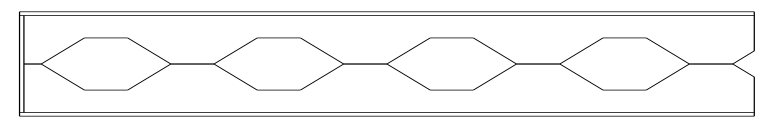

(c)

Figure 6 Illustration of making castellated beams with hexagonal openings, (a) the process of making hexagonal patterns, (b) cutting the beams into two parts, (c) merging castellated beams into a single unit
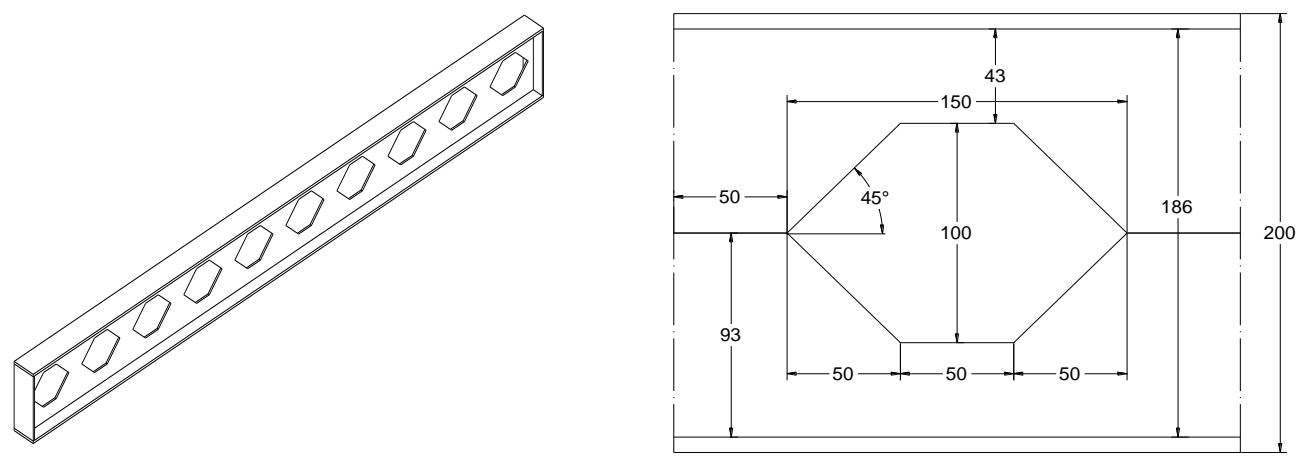

Figure 7 Hexagonal opening Castellated beam model with opening angle of $45^{0}$ [10]

The hexagonal castellated beam will be compared with the circle opening castellated beam. In this research, a castellated beam with circle openings will be made from steel profiles WF $150 \times 75 \times 5 \times 7$ with a long span of $2000 \mathrm{~mm}$ with variations in the parameters of S/Do and D/Do. This WF profile is the same as that used in hexagonal opening castellated beams.

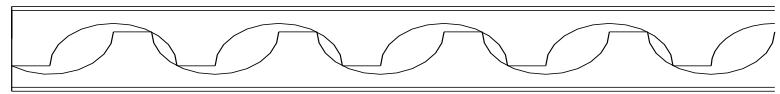

(a)

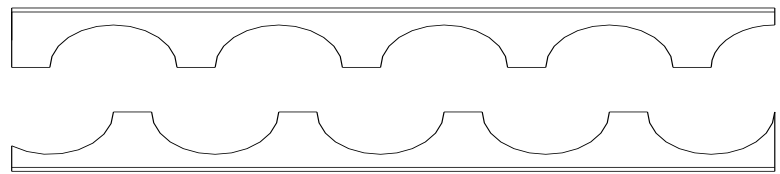

(b)

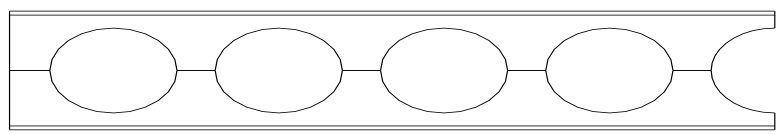

(c)

Figure 8 Illustration of making castellated beams with circle openings, (a) the process of making circle patterns, (b) the results of cutting the beams into 2 parts, (c) merging castellated beams into a single unit 
Table 2 List of Test Object Model

\begin{tabular}{ccccccccc}
\hline Model & Do & S & e & D & S/Do & D/Do & Sketch \\
\hline C1 & 150 & 165 & 15 & 223 & 1.1 & 1.49 & \\
C2 & 150 & 180 & 30 & 218 & 1.2 & 1.45 & \\
C3 & 150 & 195 & 45 & 210 & 1.3 & 1.40 & \\
C4 & 150 & 210 & 60 & 195 & 1.4 & 1.30 & & \\
C5 & 195 & 214.5 & 19.5 & 245.5 & 1.1 & 1.26 & & \\
C6 & 195 & 234 & 39 & 239 & 1.2 & 1.23 & \\
C7 & 195 & 253.5 & 58.5 & 228 & 1.3 & 1.17 & \\
\hline
\end{tabular}

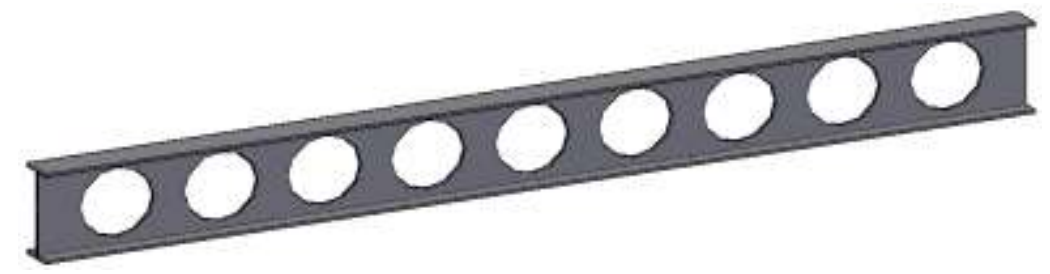

Figure 9 3D sketch of the test object model

\subsection{Test Setup}

Modeling is made with 3D Autocad program with solid objects. Then export the file to the ANSYS program. The test object is a beam with a span of $2000 \mathrm{~mm}$, supported on two simple supports, namely hinge and rollers. The load given is in the form of two points load in the middle of the span with a distance between the load points as far as $200 \mathrm{~mm}$. This two-point load is intended so that the internal forces that occur in the middle of the beam span are pure moments, without any shear forces. Because the shear between the two points of the load is zero. So that the result that is read is purely due to the force in the moment only. The load is applied gradually to the beam, until it reaches collapse. For deflection readings, a nodal deformation direction is given on the lower side of the beam right in the middle of the span.

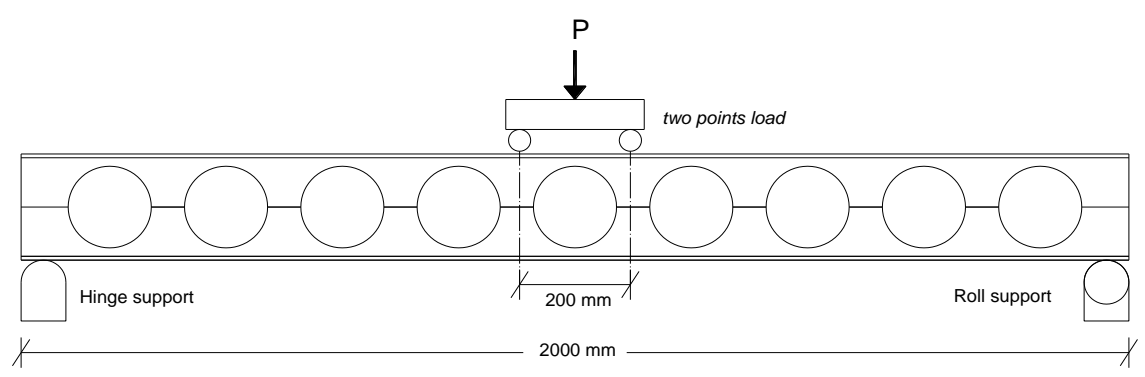

Figure 10 Test setup illustration

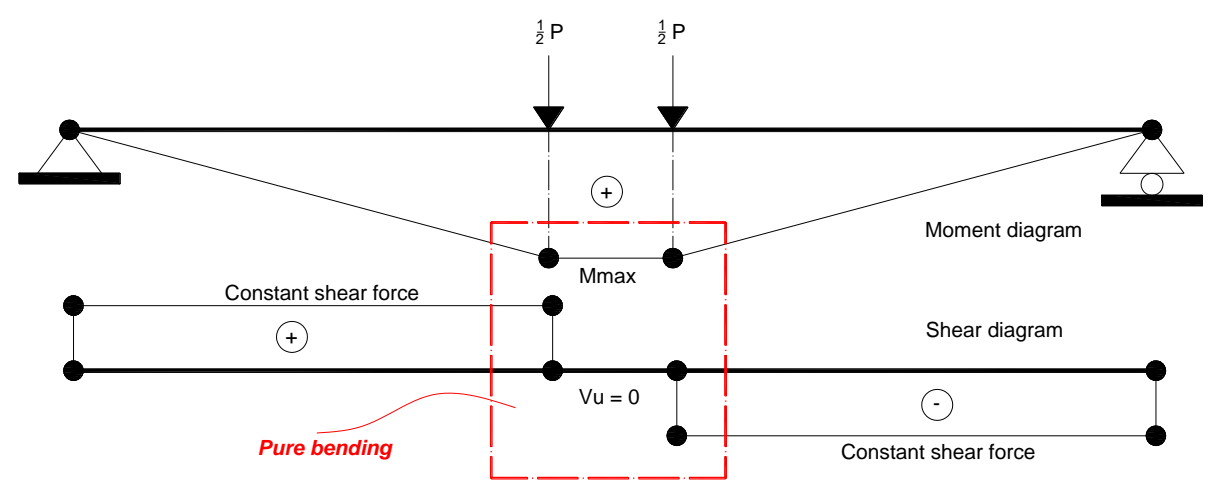

Figure 11 Diagram illustration of forces in moments and shears on beams [10] 
The load that will be given to each test model is carried out by the load step. Load steps is given 20 times. The load will be increased slowly until the running numeric results show the ultimate capacity. The model is also given a mesh element with a spacing of $25 \mathrm{~mm}$. The mesh element is carried out so that the deformation contours and stress values become smoother and more accurate. The test setup is shown in the following figure.

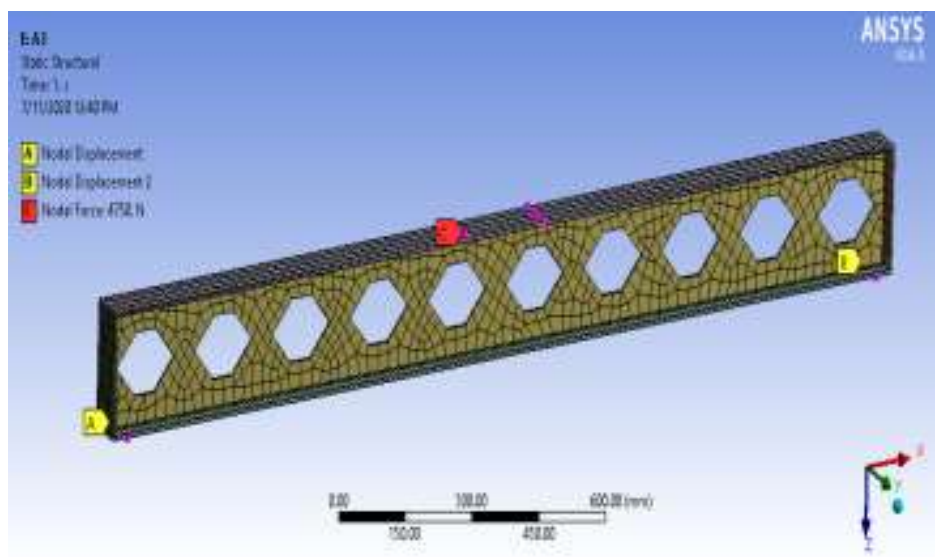

Figure 12 Numerical testing setup of castella beams with $45^{\circ}$ hexagonal opening angle

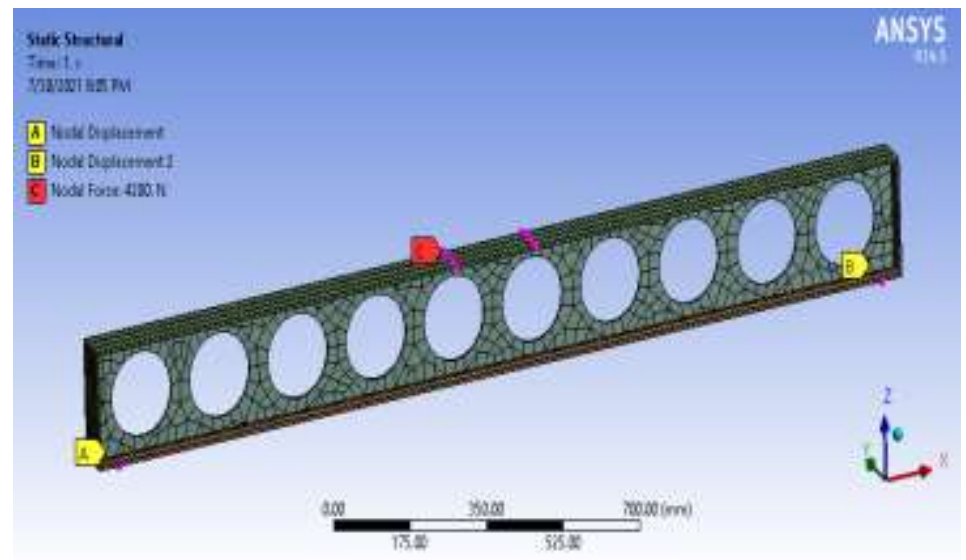

Figure 13 Numerical testing setup of castella beams with circle openings

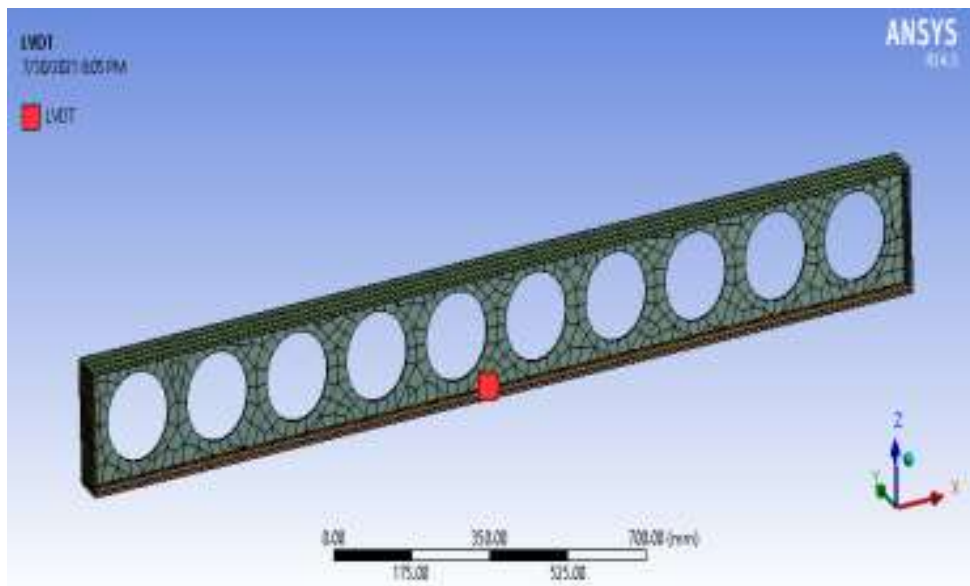

Figure 14 The position of the nodal deformation direction, to measure the deflection in the middle of the span 


\section{RESULT AND DISCUSSION}

\subsection{Bending Capacity of Castellated Beam Hexagonal opening angle 450 [10]}

In 2020, the author conducted a study on the bending behavior of hexagonal opening castellated beams. In this study, manual mathematical analytical testing and numerical analysis were carried out on several models of hexagonal opening angle variations. The variations in the opening angles are angles of $0^{\circ}$ (conventional beams), $20^{\circ}, 30^{\circ}, 45^{\circ}, 50^{\circ}$, and $60^{\circ}$. The optimum opening angle is obtained from these variations at $45^{\circ}$ with yield load $(P y) 61.7 \mathrm{kN}$ and peak load $(P u)$ bearable is $95 \mathrm{kN}$.

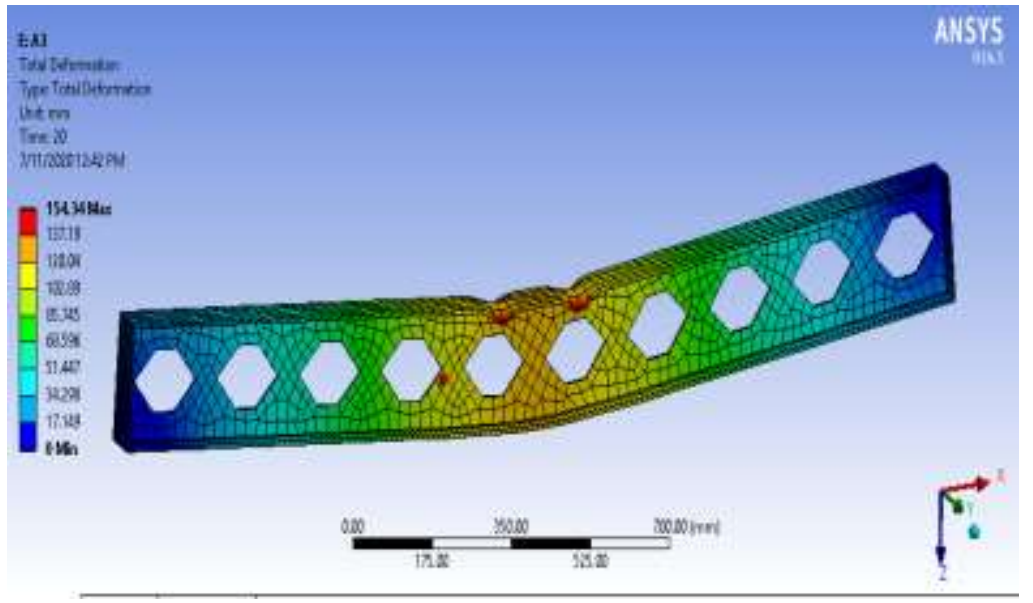

Figure 15 Shape deformation of castellated beam with $45^{\circ}$ hexagonal opening angle

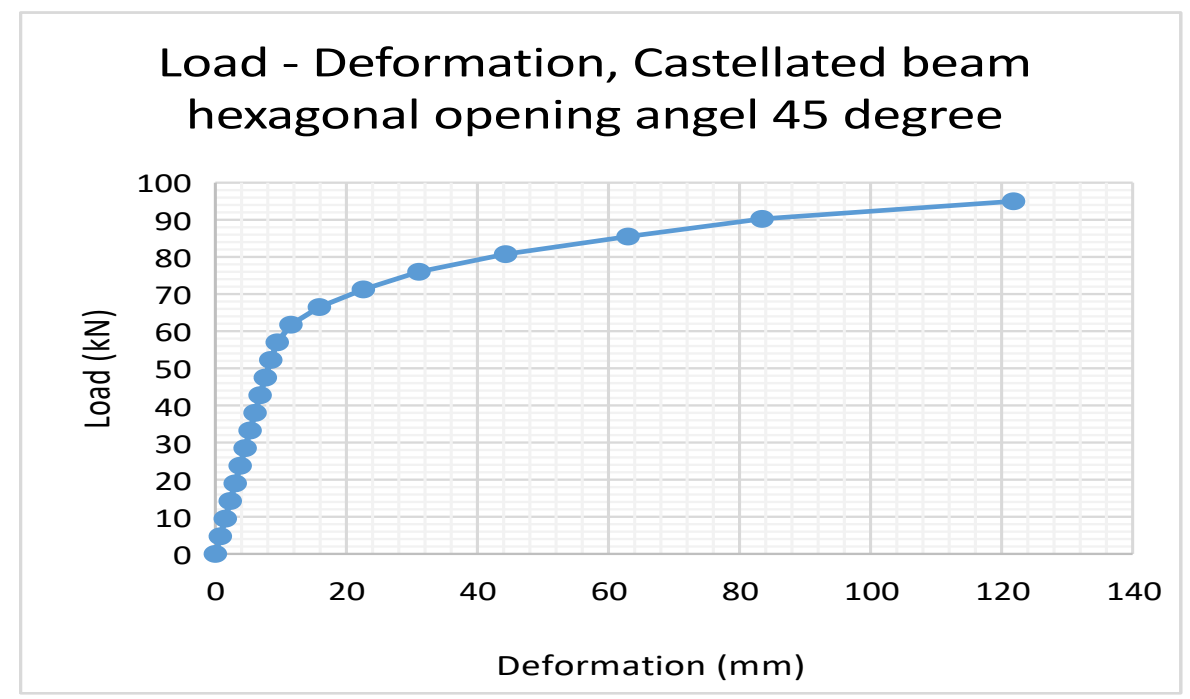

Figure 16 Load-deformation curve of castellated beam with $45^{\circ}$ hexagonal opening angle

Castellated beams with $45^{0}$ hexagonal opening angles get the greatest flexural capacity values compared to several other opening angles. With this, it can be said that converting conventional WF beams into castellated beams with $45^{\circ}$ hexagonal opening angles can increase flexural capacity. The increase in the inertia value of the hexagonal opening castellated beam increases the flexural capacity more than the conventional WF beam. Hayder Wafi [12], castellated beams can increase the ultimate strength by about $50 \%$ than the initial conventional profile.

Based on these results, then castellated beams with $45^{\circ}$ hexagonal opening angles will be compared with the value of their flexural capacity with circle castellated beams. 


\subsection{Bending Capacity of Castellated Beams Circle Opening}

To compare the flexural capacity of the hexagonal castellated beam with the circle opening, a similar test setup was carried out, namely the beam span and the same load position on the hexagonal opening castellated beam. There are seven variations of the circle opening beam model with variations in the values of S/Do and D/Do. The deformation contours for each model are shown in Table 3.

Table 3. Shape Deformation of Model Castellated Beam Circle Opening

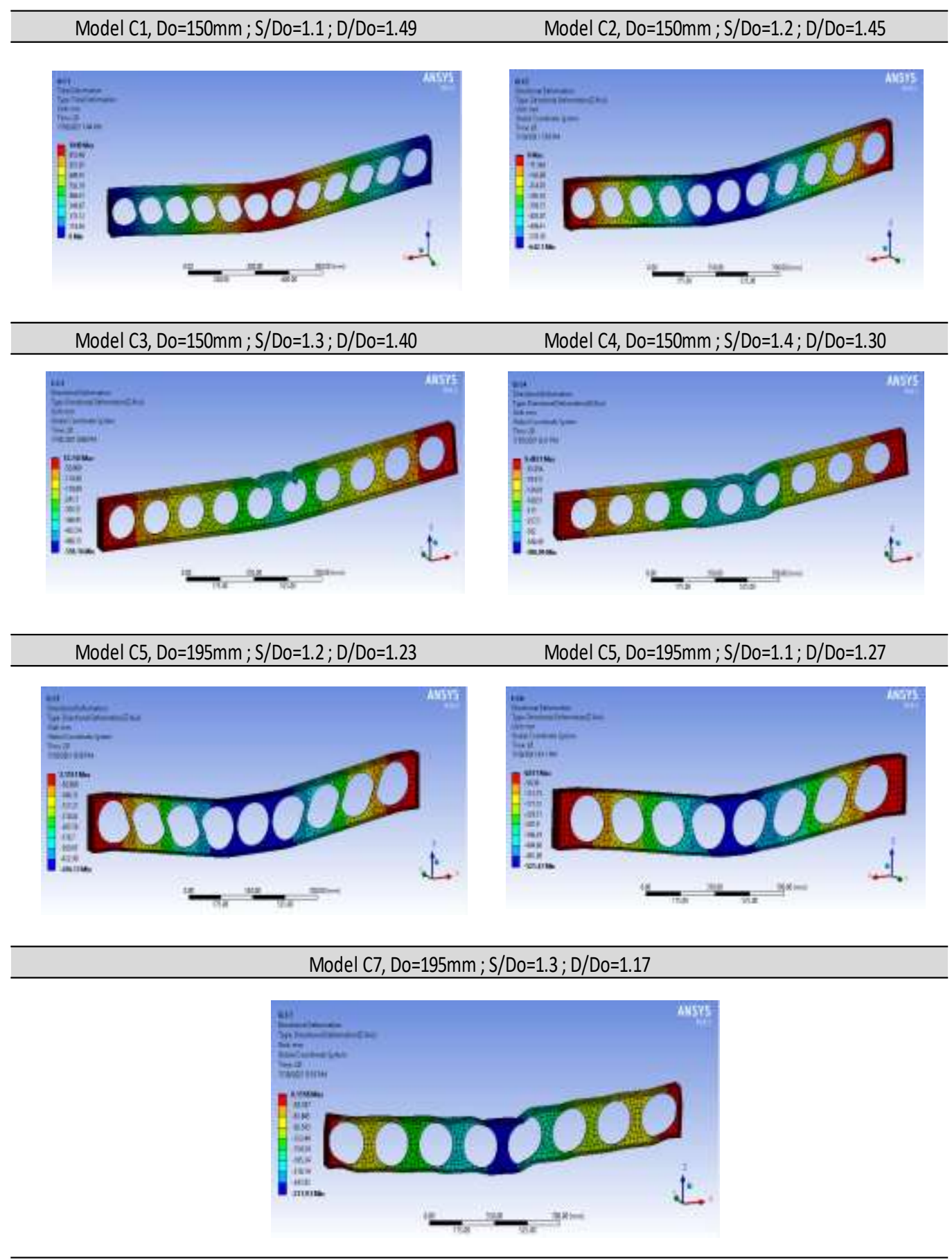




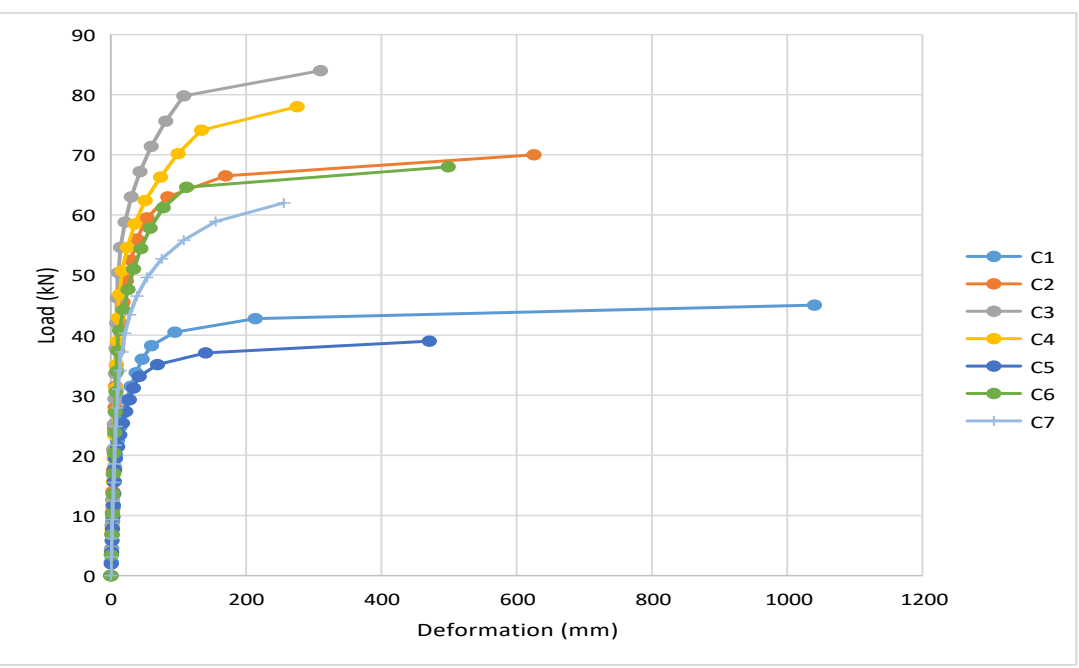

Figure 17 Load-deformation curve of model castellated beam circle opening

In this result, when viewed from the S/Do parameter values ranging from 1.1 to 1.3 , the flexural capacity value continues to increase along with the D/Do parameter which decreases from 1.49 to 1.4. However, at the value of S/Do equal to 1.4 and D/Do equal to 1.3, there is a decrease in flexural capacity. If it is continued with a smaller D/Do parameter value from 1.23 to 1.17 , then the flexural capacity is lower than the capacity of the previous model. So, to get the most optimum capacity of the castellated beam with circle openings, two important parameters must be considered, namely S/Do and D/Do. The results of running numerical ANSYS on the circle-opening castellated beam model obtained the optimum value in the C3 model, namely the parameters $\mathrm{S} / \mathrm{Do}=1.3$ and $\mathrm{D} / \mathrm{Do}=1.4$ with yield load $(\mathrm{Py})=57 \mathrm{kN}$ and ultimate load $(\mathrm{Pu})=84 \mathrm{kN}$. When viewed from the castellated beam, the circle openings of the $\mathrm{C} 1$ and C5 models are not very suitable for use, because they have the smallest load-carrying capacity. Models C1 and C5 experience very large deformations compared to other variations of circle opening models. This is because the value of the ratio of S/Do and D/Do is not balanced. The best model in carrying the load is the ratio of S/Do and D/Do, which is almost similar to the range of 1.3 - 1.4. Jamadar et al [13], the S/Do ratio of 1.4 and the D/Do ratio of 1.36 showed the most optimum value in carrying the load.

\subsection{Comparison of Bending Capacity of Hexagonal Opening Castellated Beams with Circle opening}

In order to obtain the optimum geometry of the openings for castellated beams in terms of increasing flexural capacity, a comparison is made of the results of castellated beams with $45^{\circ}$ hexagonal opening angles and circle castellated beams with $\mathrm{S} / \mathrm{Do}=1.3 ; \mathrm{D} / \mathrm{Do}=1.4$. The results of the comparison of the two can be seen in the following figure.

The value of the flexural capacity of the castellated beam with circle openings can only give $P y=57 \mathrm{kN}$ and $P u=84 \mathrm{kN}$, while the flexural capacity that the hexagonal castellated beam can give is higher at $P y=61.7 \mathrm{kN}$ and $P u=95 \mathrm{kN}$. This shows that the hexagonal castellated beam can provide a more optimum flexural capacity value than the circle opening. From the magnitude of the deformation that occurs in the beam, it is shown that the hexagonal opening castellated beam is stiffer than the circle opening. This is because the hexagonal castellated beam has a larger inertia value. And the circle opening castellated beam has a larger opening area than the hexagonal opening which causes the stiffness value to decrease. 


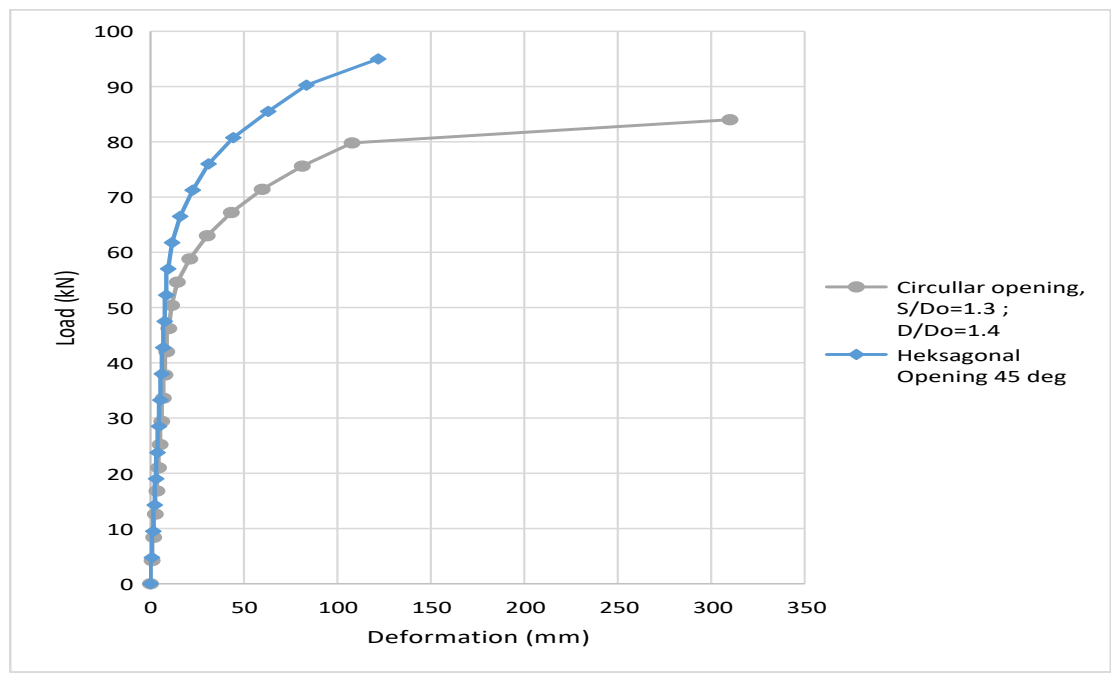

Figure 18 Load-deformation curve comparation of castellated beam hexagonal opening and circle opening

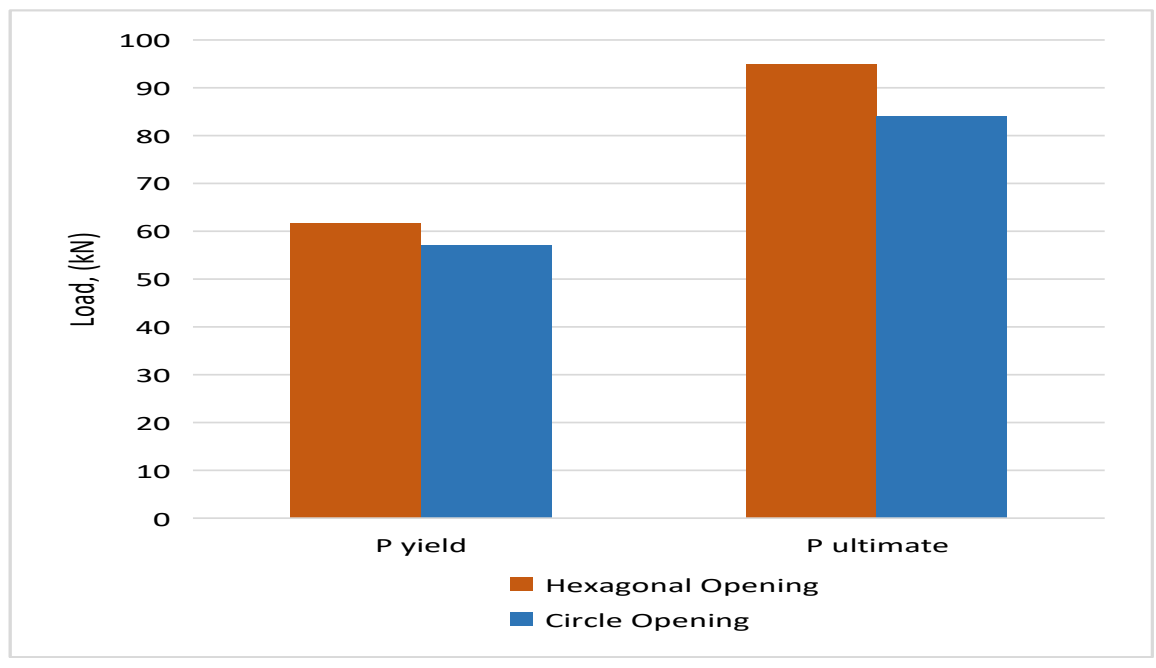

Figure 19 Load capacity comparation of castellated beam hexagonal opening and circle

Atteshamuddin et al [14], based on the value of the deflection that occurs, the most optimum opening shape of the castellated beam is a hexagonal opening. Bhosale G.A et al [9], based on the comparison of the shape of the hexagonal, square, and circle openings, the most optimum is the hexagonal opening. Samadhan et al [15], beams with hexagonal openings produce the best capacity from other variations of openings. Fatimah De'nan et al [16], hexagonal openings have the smallest deflection value compared to other variations of openings.

\section{CONCLUSION}

Castellated beam can increase the flexural capacity of a conventional WF beam. Castellated beam has several variations in the shape of the opening. For hexagonal openings, the optimum flexural capacity results at an angle of $45^{\circ}-50^{\circ}$. And for circle openings, the optimum flexural capacity is obtained at parameters $\mathrm{S} / \mathrm{Do}=1.3 ; \mathrm{D}=\mathrm{Do}=1.4$. From the results of both, when compared between the flexural capacity of hexagonal openings and circle openings, the most optimum form of the opening is the hexagonal opening. Judging from the deformation value that occurs, the circle opening has a larger deformation than the hexagonal opening. This shows 
that the circle opening has a smaller inertial stiffness than the hexagonal opening. And the circle opening has a larger hole area, thus reducing the inertia value.

\section{REFERENCES}

[1] Hayder Wafi Ali Al-Thabhawee, and Muslim Abdul-Ameer Al-Kannoon, "Improving Behavior of Castellated Beam by Adding Spacer Plat and Steel Rings," Journal of University of Babylon, Engineering Sciences, vol. 26, no. 4, pp. 331-344, Feb. 2018.

[2] Samadhan G. Morkhade, "Behavior of Castellated Steel Beams: State of the Art Review," Electronic Journal of Structural Engineering, vol. 19, no. 1, pp. 39-48, 2019.

[3] MR. Nikhil Deshmukh, and Dr. Ashok Kasnale, "Behaviour of Castellated Beam with Coupled Stiffener," International Research Journal of Engineering and Technology (IRJET), vol. 6, no. 6, pp. 353-360, June 2019.

[4] H W Al-Thabhawee and A Mohammed, "Experimental Study for Strengthening Octagonal Castellated Steel Beams using Circular and Octagonal Ring Stiffeners," in International Conference on Civil and Environmental Engineering Technologies, IOP Conf. Series: Materials Science and Engineering Vol 584, 2019.

[5] Samadhan G. Morkhade et al, "Structural behaviour of castellated steel beams with reinforced web openings," Asian Journal of Civil Engineering, May 2020. DOI: 10.1007/s42107-02000262-y.

[6] Guruprasad. D. Kulkarni, and Rahul.D. Patil, "Experimental Study of Behavior of Castellated Beam with Diamond Shape Opening Under Lateral -Torsional Buckling," International Journal of Engineering Research \& Technology (IJERT), vol. 9, no. 9, pp. 466-469, Sep. 2020.

[7] Armin Aryadi, "Behavior of Castellated Steel Beam under Cyclic Loads," Dintek, vol. 12, no. 2, pp. 92-102, Sep. 2019.

[8] Rohit Kurlapkar, and D.B. Kulkarni, "Behavior of Castellated Beam with Sinusoidal Openings," International Research Journal of Engineering and Technology (IRJET), vol. 6, no. 4, pp. 2478-2480, April 2019.

[9] Bhosale G.A et al, "Comparative Study of Flexural Behaviour Of Castellated Beam For Different Shapes Of Openings," International Journal of Engineering Technology Science and Research (IJETSR), vol. 4, no. 4, pp. 71-78, April 2017.

[10] I Barkiah and A R Darmawan, "Comparative analysis of the flexural capacity of conventional steel beams with Castellated beams," in Proc. 3rd International Seminar on Livable Space, IOP Conf. Series: Earth and Environmental Science Vol 780, Jakarta, Indonesia, 2021.

[11] Darmawan AR et al, "Perilaku plate girder Badan Bergelombang," Rekayasa Sipil, vol. 11, no. 2, pp 116-123, 2017.

[12] Hayder Wafi Ali Al-Thabhawee, "Experimantal Study of Effect of Hexagonal Holes Dimensions on Ultimate Strength of Castellated Steel Beam," Kufa Journal of Engineering, vol. 8, no. 1, pp. 97-107, Jan. 2017.

[13] Jamadar A. M and Kumbhar P. D., "Parametric Study of Castellated Beam with Circular Opening (Cellular Beam)," in National Conference for Engineering Post Graduates RIT NConPG , 15. ISBN-13:978-1512094169 
[14] Atteshamuddin S. Sayyad and Ajim S. Shaikh, "Estimation of Deflections in Cantilever and Fixed Castellated Beams with Hexagonal, Square and Circular Openings," TECNICA ITALIANA-Italian Journal of Engineering Science, vol. 64, no. 1, pp. 118-127, March 2020.

[15] Samadhan G. Morkhade et al, "Experimental and Analytical Investigation of Castellated Steel Beams with Varying Openings Eccentricity," Journal of The Institution of Engineers (India) Series A, DOI: 10.1007/s40030-021-00516-1, Feb. 2021.

[16] Fatimah De'nan et al, "Shapes and Sizes of Web Opening Effects on Bending Behaviour of IBeam with Web Opening," in AIP Conference Proceedings 1892, 020021, DOI: 10.1063/1.5005652, Oct. 2017. 